\title{
Pengaruh Substitusi Bungkil Kedelai dengan Bungkil Wijen Lokal Terhadap Efisiensi Protein dan Performan Ayam Broiler
}

\author{
I. Astuti \\ Jurusan Peternakan, Fakultas Pertanian, Universitas Sebelas Maret \\ Jl. Ir. Sutami 36 A, Kentingan, Surakarta
}

\begin{abstract}
INTISARI
Penelitian ini dilakukan di Kandang Percobaan Jurusan Peternakan, Fakultas Pertanian, Universitas Sebelas Maret, Surakarta. Tujuan penelitian adalah untuk mengevaluasi performan produksi dan efisiensi protein ayam broiler yang mendapat substitusi bungkil kedelai dengan bungkil wijen lokal. Lima perlakuan dialokasikan dalam Rancangan Acak Lengkap (RAL). Setiap perlakuan diulang lima kali dengan empat ekor ayam pada setiap unit ulangan. Perlakuan ransum yang diujikan adalah substitusi bungkil kedelai (BK) dengan bungkil wijen lokal (BWL) dengan taraf sebagai berikut: P0 : $100 \mathrm{BK}+0 \% \mathrm{BWL}$; 1 : 90\% BK+10\% BWL; P2 : $80 \%$ BK + 20\% BWL; P3 : 70\% BK+ 30\% BWL; P4 : 60\% BK+ 40\% BWL. Peubah yang diamati meliputi konsumsi ransum, pertambahan bobot badan, konversi ransum dan efisiensi protein. Data dianalisis menggunakan sidik ragam.

Hasil analisis menunjukkan bahwa semua peubah yang diamati tidak menunjukkan perbedaan nyata $(\mathrm{P} \geq 0,05)$. Rataan konsumsi ransum (g/ekor/hari) $(92,76 ; 90,13 ; 90,87 ; 87,10$ dan 89,31); pertambahan bobot badan (g/ekor/hari) $(47,16 ; 45,99 ; 47,03 ; 45,46$ dan 45,76); konversi ransum $(1,95 ; 1,97 ; 1,93 ; 1,96$ dan 1,95$)$ serta efisiensi protein $(2,31 ; 2,27$; 2,25; 2,31; dan 2,28) masing-masing untuk perlakuan P0, P1, P2, P3 dan P4. Kesimpulan dari penelitian ini adalah bahwa bungkil wijen lokal dapat dipergunakan untuk mensubstitusi $40 \%$ penggunaan bungkil kedelai dalam ransum broiler sampai umur 42 hari.
\end{abstract}

Kata kunci : bungkil kedelai, bungkil wijen lokal, performan, efisiensi protein, broiler

\section{The Effect of Substitution of Soybean Meal With Local Sesame Meal on The Performance and Protein Efficiency Ratio of Broiler Chickens}

\begin{abstract}
The obyective of this experiment was to study the effect of substitution of soybean meal with local sesame meal on performance and protein effisiency ratio of broiler chicken. One hundred of broiler chickens strain Lohman were allocated in Completely Randomized Design with five replication and four chicken of each. The treatments were $P 0: 100 \% B K+0 \%$ $B W L ; P 1$ : $90 \% B K+10 \% B W L ; P 2 ; 80 \% B K+20 \% B W L ; \quad P 3: 70 \% B K+30 B W L$ and P4: $60 \%$ BK+ 40\% BWL. Variable measured were feed consumption, average daily gain, feed conversion and protein efficiency ratio. Data were analyzed with analysis of variance (ANOVA).

The result of this research indicated that treatments were not significant effect to the all variables. Average feed consumption (g/head/d) of: (92,76; 90,13; 90,87; 87,10 dan
\end{abstract}


$89,31)$; average daily gain (g/head/d) of : $(47,16 ; 45,99 ; 47,03 ; 45,46$ dan 45,76); average of feed conversion of : $(1,95 ; 1,97 ; 1,93 ; 1,96$ dan 1,95) and protein efficiency ratio of: $(2,31 ; 2,27 ; 2,25 ; 2,31$; dan 2,28) for P0, P1, P2, P3 and P4, respectively. It was concluded that $40 \%$ of soybean meal could be substituted with local sesame meal in diet of broiler that reared up to 42 days of age.

Key words: soybean meal, local sesame meal, performance, efficiency protein, broiler

\section{PENDAHULUAN}

Peternakan ayam broiler merupakan sektor yang efisien dan cepat dalam menyediakan pangan hewani dalam bentuk daging. Ayam broiler dikenal mempunyai tingkat pertumbuhan yang cepat, sehingga pada umur delapan minggu sudah dapat dipasarkan. Akan tetapi terdapat kendala yang mendasar yaitu tingginya biaya ransum yang dapat mencapai 60 sampai $70 \%$ dari biaya produksi (Rasyaf, 1994a). Tersedianya ransum yang berkualitas dalam jumlah yang mencukupi serta pengelolaan yang tepat merupakan faktor penting untuk menentukan keberhasilan budidaya ayam pedaging.

Ransum disusun dari berbagai bahan pakan yang diramu dengan formula tertentu agar dapat memenuhi kebutuhan nutrien ayam. Salah satu bahan pakan sumber protein yang hampir selalu digunakan sebagai penyusun ransum ayam adalah bungkil kedelai yang sampai saat ini pengadaannya masih bergantung dari produk impor. Penggunaan bungkil kedelai dalam formula ransum ayam pedaging dapat mencapai 30\% (Rasyaf, 1994b). Untuk mengatisipasi terjadinya gejolak pakan maka perlu dicari bahan pakan alternatif yang bersumber dari bahan pakan lokal namun memiliki kandungan nutrien yang memadai, tidak bersaing dengan kebutuhan manusia, aman dan mudah tersedia.

Di Jawa Tengah khususnya di Kabupaten Sukoharjo terdapat beberapa home industry pengolahan minyak wijen. Salah satu hasil ikutan pengolahan minyak wijen adalah bungkil wijen (sesame meal). Di negara penghasil biji wijen seperti India, Mesir, Iraq, Thailand dan China, bungkil wijen telah lazim digunakan sebagai salah satu bahan formula ransum (Daghir, 1995). Namun di Indonesia, khususnya di Kabupeten Sukoharjo dan sekitarnya, bungkil wijen ini belum banyak dimanfaatkan sebagai bahan pakan.

Kandungan nutrien bungkil wijen lokal yang diproduksi di daerah Sukoharjo adalah Protein kasar 40,85\%, Serat kasar 4,75\%, dan Lemak kasar $19,60 \%$ dan Energi Metabolis $4178 \mathrm{kkal} / \mathrm{kg}$. Rendemen minyak yang diperoleh pada pengolahan home industry ini belum maksimal, baru diperoleh sekitar 30\% dari berat biji wijen, sementara kandungan minyak pada bungkilnya masih cukup tinggi yaitu antara 16-19\%. Jika dibanding dengan kandungan minyak pada bungkil wijen impor yang hanya berkisar 3 - 5\% maka hasil minyak yang diperoleh home industri di Sukoharjo belum maksimal. Hal ini diduga karena proses ekstraksi minyak dilakukan masih sederhana yaitu dengan esktraksi mekanik menggunakan kempa press biasa (Handayani, et al., 2001).

Mengingat kandungan proteinnya yang cukup tinggi, maka bungkil wijen lokal ini dapat dijadikan sumber protein alternatif pengganti sebagian bungkil kedelai dalam ransum ayam broiler. Subsitusi bungkil kedelai dengan bahan lain juga pernah diteliti oleh Rizal (2000) yaitu subsitusi bungkil kedelai dengan bungkil inti sawit dalam ransum sampai taraf $40 \%$ tidak menurunkan performan ayam broiler. Sementara Daghir (1995) menyatakan bahwa bungkil wijen dapat menggantikan $50 \%$ bungkil kedelai ketika disuplementasi dengan asam amino lisin sintetik 0,32\%. Tujuan penelitian adalah untuk mengetahui respon produksi dan efisiensi protein 
ransum akibat substitusi bungkil kedelai dengan bungkil wijen lokal yang diukur melalui konsumsi ransum, pertambahan bobot badan, konversi ransum dan efisiensi protein. Jika penelitian ini memberikan hasil yang positif maka akan diperoleh bahan pakan sumber protein dari lokal yang dapat digunakan untuk menggantikan atau sekurang-kurangnya sebagai substituisi bahan pakan impor (bungkil kedelai) khususnya dalam ransum ayam broiler.

\section{MATERI DAN METODE}

Penelitian dilaksanakan di kandang percobaan Jurusan Peternakan Fakultas Pertanian Universitas Sebelas Maret, Surakarta, selama 42 hari. Bahan yang digunakan dalam penelitian ini adalah seratus ekort DOC broiler jantan strain Lohman.

Ransum komersial BR1 digunakan pada masa pra penelitian (umur 1-3 hari), sedangkan ransum penelitian adalah ransum self mixing dengan bahan jagung kuning, bekatul, bungkil kedelai, tepung ikan, mineral premiks yang diperoleh dari distributor pakan PT. Tirta Mas di Surakarta, dan bungkil wijen lokal yang diperoleh dari home industry di Kecamatan Bendosari, Kabupaten Sukoharjo. Selama penelitian, ransum dan air minum diberikan secara ad libitum. Kandungan nutrien bahan pakan dan formula ransum perlakuan disajikan pada Tabel 1, 2 dan 3.

Tabel 1. Kandungan Nutrien Bahan Pakan

\begin{tabular}{|c|c|c|c|c|c|c|}
\hline \multirow[t]{2}{*}{ Bahan pakan } & \multirow{2}{*}{$\begin{array}{c}\mathrm{ME} \\
(\mathrm{kkal} / \mathrm{kg})\end{array}$} & $\begin{array}{c}\text { Protein } \\
\text { Kasar }\end{array}$ & $\begin{array}{l}\text { Serat } \\
\text { Kasar }\end{array}$ & Lemak & $\mathrm{Ca}$ & $\mathrm{P}$ \\
\hline & & \multicolumn{5}{|c|}{ 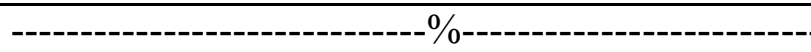 } \\
\hline Jagung kuning $^{1)}$ & 3321 & 8,90 & 2,20 & 4,00 & 0,02 & 0,23 \\
\hline Bekatul 1) & 2887 & 12,00 & 5,20 & 10,70 & 0,04 & 1,27 \\
\hline Bk. Kedelai ${ }^{1)}$ & 3421 & 41,30 & 5,30 & 4,90 & 0,24 & 0,56 \\
\hline Bk.Wijen lokal ${ }^{2)}$ & $3248^{3)}$ & 40,85 & 4,75 & 19,60 & 1,99 & 1,37 \\
\hline Tp ikan ${ }^{1)}$ & 3281 & 52,60 & 2,20 & 6,80 & 5,68 & 3,73 \\
\hline
\end{tabular}

Tabel 2. Komposisi dan Kandungan Nutrien Ransum Fase Awal

\begin{tabular}{|c|c|c|c|c|c|}
\hline \multirow{2}{*}{ Bahan Pakan } & \multicolumn{5}{|c|}{ Perlakuan } \\
\hline & $\mathrm{P} 0$ & P1 & $\mathrm{P} 2$ & $\mathrm{P} 3$ & $\mathrm{P} 4$ \\
\hline Jagung kuning & 46,00 & 46,00 & 46,00 & 46,00 & 46,00 \\
\hline Bekatul & 10,00 & 10,00 & 10,00 & 10,00 & 10,00 \\
\hline Bk. Kedelai & 32,50 & 29,25 & 26,00 & 22,75 & 19,50 \\
\hline Bk.Wijen lokal & 0 & 3,25 & 6,50 & 9,75 & 13,00 \\
\hline Tp ikan & 8,00 & 8,00 & 8,00 & 8,00 & 8,00 \\
\hline Premix + garam & 3,50 & 3,50 & 3,50 & 3,50 & 3,50 \\
\hline Jumlah & 100 & 100 & 100 & 100 & 100 \\
\hline Kandungan nutrie & & & & & \\
\hline Protein kasar $(\%)$ & 22,92 & 22,91 & 22,90 & 22,89 & 22,87 \\
\hline $\operatorname{ME}(\mathrm{kkal} / \mathrm{kg}) * *)$ & 3190,67 & 3185,05 & 3179,43 & 3174,08 & 3168,67 \\
\hline Lemak kasar (\%) & 5,50 & 5,52 & 6,00 & 6,48 & 6,96 \\
\hline Serat kasar (\%) & 3,43 & 3,42 & 3,39 & 3,38 & 3,36 \\
\hline $\mathrm{Ca}(\%)$ & 1,98 & 2,03 & 2,02 & 2,04 & 2,06 \\
\hline $\mathrm{P}(\%)$ & 1,84 & 1,86 & 1,90 & 1,91 & 1,92 \\
\hline
\end{tabular}


Keterangan :

*) Hasil analisis Lab. Nutrisi dan Makanan Ternak, Jur. Peternakan, Fak. Pertanian UNS

**) $\mathrm{ME}=3951+(4,4 \mathrm{xLK})-(88,7 \mathrm{xSK})-(40,8 \mathrm{x}$ abu $)$ (Sibbald, 1980)

Tabel 3. Komposisi dan Kandungan Nutrien Ransum Fase Akhir

\begin{tabular}{lccccc}
\hline \hline \multirow{2}{*}{ Bahan Pakan } & \multicolumn{5}{c}{ Perlakuan } \\
\cline { 2 - 6 } & P0 & P1 & P2 & P3 & P4 \\
& 49,00 & 49,00 & 49,00 & 49,00 & 49,00 \\
\hline Jagung kuning & 15,50 & 15,50 & 15,50 & 15,50 & 15,50 \\
Bekatul & 25,00 & 22,50 & 20,00 & 17,50 & 15,00 \\
Bk. Kedelai & 0 & 2,50 & 5,00 & 7,50 & 10,00 \\
Bk.Wijen lokal & 7,00 & 7,00 & 7,00 & 7,00 & 7,00 \\
Tp ikan & 3,50 & 3,50 & 3,50 & 3,50 & 3,50 \\
Premix + garam & $\mathbf{1 0 0}$ & $\mathbf{1 0 0}$ & $\mathbf{1 0 0}$ & $\mathbf{1 0 0}$ & $\mathbf{1 0 0}$ \\
$\quad$ Jumlah & & & & & \\
Kandungan nutrien *) & 20,23 & 20,22 & 20,21 & 20,19 & 20,19 \\
Protein kasar (\%) & 3159,67 & 3138,24 & 3133,92 & 3129,60 & 3125,27 \\
ME (kkal/kg) **) & 5,32 & 5,69 & 6,05 & 6,42 & 6,76 \\
Lemak kasar (\%) & 3,36 & 3,35 & 3,34 & 3,32 & 3,31 \\
Serat kasar (\%) & 1,98 & 1,96 & 2,02 & 2,04 & 2,06 \\
Ca (\%) & 1,84 & 1,86 & 1,87 & 1,89 & 1,92 \\
P (\%)
\end{tabular}

Keterangan :

*) Hasil analisis Lab. Nutrisi dan Makanan Ternak, Jur. Peternakan, Fak. Pertanian UNS **) $\mathrm{ME}=3951+(4,4 \mathrm{xLK})-(88,7 \mathrm{xSK})-(40,8 \mathrm{x}$ abu $)$ (Sibbald, 1980)

Sebanyak 100 ekor ayam yang ditempatkan dalam 25 unit kandang petak ukuran $1,0 \mathrm{~m} \times 0,6 \mathrm{~m}$ x $0,5 \mathrm{~m}$ berlantai litter dengan alas sekam yang dicampur sedikit kapur. Setiap petak dilengkapi dengan tempat pakan, tempat minum dan lampu penghangat, yang diisi dengan empat ekor ayam sebagai unit ulangan, Untuk menimbang ransum dan ayam digunakan timbangan berkapasitas $5 \mathrm{~kg}$ dengan kepekaan 20 gram. Sebelum digunakan, kandang dan peralatannya disucihamakan dengan antiseptik formalin dengan dosis 10 $\mathrm{ml} / 2,5$ liter air.

Day Old Chick (DOC) ayam broiler yang baru tiba dimasukkan ke dalam kandang brooder, diberi minum air gula 2\% dan vita stress. Ransum yang diberikan sampai umur tiga hari adalah ransum komersial BR1. Pada hari ke empat dilakukan vaksinasi ND dengan menggunakan vaksin ND B1 yang diberikan melalui tetes mata, untuk mencegah penyakit tetelo. Umur empat sampai tujuh hari ayam diadaptasikan dengan rasum perlakuan. Pada umur tujuh hari ayam ditimbang untuk mencari bobot yang homogen, diberi nomor pada sayapnya, kemudian ayam ditempatkan ke dalam petak kandang secara acak. Setiap petak kandang diisi dengan empat ekor ayam.

Penelitian ini menggunakan Rancangan Acak Lengkap (RAL) pola searah dengan lima perlakuan $(\mathrm{P} 0, \mathrm{P} 1, \mathrm{P} 2$, P3 dan P4) yang masing-masing perakuan diulang lima kali dan setiap ulangan menggunakan empat ekor ayam. Perlakuan yang diujikan adalah substitusi bungkil kedelai (BK) dengan bungkil wijen lokal (BWL) dengan taraf substitusi seperti berikut:

$\mathrm{P} 0: 100 \% \mathrm{BK}+0 \% \mathrm{BWL}$

$\mathrm{P} 1: 90 \% \mathrm{BK}+10 \% \mathrm{BWL}$

$\mathrm{P} 2: 80 \% \mathrm{BK}+20 \% \mathrm{BWL}$

P3 : $70 \% \mathrm{BK}+30 \% \mathrm{BWL}$ 
P4: $60 \% \mathrm{BK}+40 \% \mathrm{BWL}$

Data yang diperoleh diolah secara statistik menggunakan analisis ragam dan apabila perlakuan berpengaruh nyata dilanjutkan dengan uji lanjut jarak berganda Duncan (Steel dan Torie, 1989). Peubah yang diukur dalam penelitian ini adalah :

a. Konsumsi ransum (g/ekor/hari), dihitung berdasarkan selisih antara jumlah ransum yang diberikan pada awal minggu (g) dengan sisa ransum pada akhir minggu (g) dibagi tujuh.

b. Pertambahan berat badan (PBB)b(g/ ekor/ hari), dihitung berdasarkan selisih bobot tubuh pada akhir minggu (g) dan bobot tubuh awal minggu (g) dibagi tujuh.

c. Konversi ransum, dihitung berdasarkan jumlah ransum yang dikonsumsi dibagi dengan PBB per satuan waktu. d. Imbangan efisiensi protein, dihitung berdasarkan PBB dibagi konsumsi protein ( Wiradisastra, 1986).

\section{HASIL DAN PEMBAHASAN}

Pengaruh perlakuan terhadap peubah yang diamati selama penelitian disajikan dalam Tabel 4.

\section{Konsumsi Ransum}

Rata-rata konsumsi ransum antar perlakuan P0, P1, P2, P3 dan P4 secara statistik berbeda tidak nyata $(\mathrm{P}>0,05)$. Hal ini menunjukkan bahwa substitusi bungkil kedelai dengan bungkil wijen lokal sampai taraf $40 \%$ tidak mengubah palatabilitas sehingga tidak mempengaruhi konsumsi ransum.

Tabel 4. Pengaruh Perlakuan terhadap Konsumsi Ransum, PBB, Konversi Ransum dan Efisiensi Protein

\begin{tabular}{lccccc}
\hline \hline \multirow{2}{*}{ Peubah } & \multicolumn{4}{c}{ Taraf substitusi Bungkil Kedelai dengan Bungkil Wijen Lokal } \\
\cline { 2 - 6 } & $0 \%$ & $10 \%$ & $20 \%$ & $30 \%$ & $40 \%$ \\
\hline $\begin{array}{l}\text { Konsumsi ransum } \\
\text { (g/ekor/hari) }\end{array}$ & $92,76^{\text {a }}$ & $90,13^{\text {a }}$ & $90,87^{\text {a }}$ & $87,10^{\text {a }}$ & $89,31^{\text {a }}$ \\
PBB (g/ekor/hari) & $47,16^{\text {a }}$ & $45,99^{\text {a }}$ & $47,03^{\text {a }}$ & $45,46^{\text {a }}$ & $45,76^{\text {a }}$ \\
Konversi ransum & $1,95^{\mathrm{a}}$ & $1,97^{\text {a }}$ & $1,93^{\text {a }}$ & $1,96^{\text {a }}$ & $1,95^{\text {a }}$ \\
Efisiensi protein & $2,31^{\text {a }}$ & $2,27^{\text {a }}$ & $2,25^{\text {a }}$ & $2,31^{\text {a }}$ & $2,28^{\text {a }}$ \\
\hline
\end{tabular}

Keterangan: Huruf kecil yang sama pada setiap baris menunjukkan berbeda tidak nyata $(\mathrm{P}>0,05)$

Diduga karena ransum dipersiapkan isoenergi dan isoprotein maka konsumsi ransum tidak terpengaruh. Ayam akan menyesuaikan jumlah ransum yang dikonsumsi berdasarkan kandungan energi dan protein dalam ransumnya (Wahyu, 1997). Ayam broiler dapat menyesuaikan konsumsi ransumnya untuk memperoleh energi yang cukup guna pertumbuhan maksimal, penyesuaian tersebut berkisar pada nilai energi antara 2800-3400 kkal $\mathrm{EM} / \mathrm{kg}$ ransum (Anggorodi, 1985).
Disamping itu kandungan serat kasar dan lemak berada dalam batas-batas kebutuhan seperti yang direkomendasikan oleh NRC (1984).

Kandungan minyak pada bungkil wijen lokal yang masih cukup tinggi, yaitu sekitar $19 \%$, sementara kandungan minyak pada bungkil wijen impor hanya sekitar 3-5\% (Daghir, 1985). Tingginya kandungan minyak pada bungkil wijen lokal disebabkan proses pengolahannya yang masih sederhana yaitu dengan ekstraksi 
mekanik, sementara bungkil wijen impor diolah dengan ekstraksi solvent. Sebagaimana dijelaskan oleh Wahyu (1997) bahwa lemak atau minyak mengandung energi 2,25 kali lebih besar dari pada karbohidrat sehingga dapat menekan konsumsi ransum. Meskipun demikian dari hasil penelitian ini terlihat bahwa penggunaan bungkil wijen sampai 13\% dalam ransum fase awal dan sampai $10 \%$ dalam ransum fase akhir tidak mempengaruhi konsumsi dibanding ransum kontrol yang tidak menggunakan bungkil wijen lokal. Salah satu kendala yang muncul dalam penelitian adalah bahwa bungkil wijen maupun ransumnya menjadi lebih mudah berjamur dan mudah tengik.

\section{Pertambahan Bobot Badan}

Rata-rata PBB ayam selama penelitian secara statistik berbeda tidak nyata $(\mathrm{P}>0,05)$. Hal ini menunjukkan kualitas ransum terutama protein ransum antar perlakuan mempunyai kualitas yang tidak berbeda selain juga disebabkan oleh konsumsi ransum ayam broiler selama penelitian relatif sama.

Menurut Hutagalung (1998) bungkil kedelai mempunyai kekurangan pada asam amino metionin, sementara bungkil wijen kaya asam amino metionin, sistin dan tripthopan akan tetapi miskin asam amino lisin dan threonin. Adanya sifat suplementer dari asam amino, akan diperoleh hasil yang baik jika kedua bahan digunakan secara bersama-sama (Aletor, et al., 2000).

Selain kualitas protein, imbangan energi dan protein ransum juga mempengaruhi pertambahan bobot badan. Panda dan Rao, 1973 cit. Ranjhan (1981) menyarankan imbangan energi dan protein ransum ayam broiler sampai umur enam minggu berkisar antara 125 sampai 143, sedangkan menurut Card (1962) dalam Murtidjo (1987) imbangan energi dan protein ayam broiler fase awal adalah 132 dan fase akhir 160. Imbangan energi dan protein dalam penelitian ini berkisar antara 131 sampai 144 pada fase awal dan 156 sampai 160 pada fase akhir yang menunjukkan berada dalam batas rekomendasi tersebut sehingga dapat memberikan pertambahan bobot badan yang tidak berbeda antar perlakuan.

Pertambahan bobot badan juga dipengaruhi faktor kecernaan nutrien. Kandungan serat kasar ransum akan mempengaruhi tingkat kecernaan dan laju nutrien dalam saluran pencernaan. Kandungan serat kasar dalam ransum perlakuan berkisar antara 3,31 sampai $3,38 \%$ dan masih dalam batas toleransi maksimum serat kasar pada unggas. Hal ini memungkinkan ransum antar perlakuan mempunyai tingkat kecernaan yang sama sehingga menghasilkan pertambahan bobot badan yang tidak berbeda (Murtidjo, 2001)

\section{Konversi Ransum}

Angka konversi ransum menggambarkan keefisienan ransum, semakin rendah angka konversi berarti ransum semakin efisien digunakan untuk membentuk daging. Efisiensi penggunaan ransum dipengaruhi oleh konsumsi ransum dan kandungan nutrien dalam ransum (Anggorodi, 1985), sedangkan menurut Rasyaf (1994) konsersi ransum dipengaruhi oleh pertambahan bobot badan dan konsumsi ransum. Dalam penelitian ini konsumsi ransum maupun pertambahan bobot badan antar perlakuan tidak berbeda nyata sehingga menghasilkan nilai konversi ransum yang tidak berbeda nyata $(\mathrm{P}>0,05)$.

Dari angka konversi ransum yang tidak berbeda nyata dengan kontrol menunjukkan bahwa bungkil kedelai dapat disubstitusi dengan bungkil wijen sampai taraf $40 \%$ dari jumlah penggunaan bungkil kedelai. Fakta ini memberikan harapan terhadap pemanfatan bahan baku alternatif dalam formula ransum.

\section{Efisiensi protein}

Nilai efisiensi protein menggambarkan kemampuan protein ransum untuk 
dikonversi menjadi daging. Nilai efisiensi protein didapatkan dari hasil perbandingan antara pertambahan bobot badan dengan konsumsi protein.

Substitusi bungkil kedelai dengan bungkil wijen lokal sampai taraf $40 \%$ tidak nyata mempengaruhi imbangan efisiensi protein $(\mathrm{P}>0,05)$.. Kandungan protein ransum sebagai akibat substitusi bungkil kedelai dengan bungkil wijen sampai taraf $40 \%$ tidak banyak berpengaruh terhadap perubahan kandungan protein ransum, hal ini karena bungkil wijen lokal mempunyai kandungan protein yang hampir sama dengan bungkil kedelai yang dipergunakan dalam penelitian ini. Rataan konsumsi ransum tidak menunjukkan perbedaan yang nyata antar perlakuan, demikian pula dengan pertambahan bobot badan.

Wahyu (1997) menjelaskan bahwa untuk sintesis protein jaringan tubuh, selain tingkat protein kasar , kecukupan asam amino terutama asam amino esensiil harus terpenuhi dalam ransum. Bungkil wijen mempunyai asam amino pembatas lisin sedangkan bungkil kedelai mempunyai asam amino pembatas metionin. Diduga pada substitusi bungkil kedelai dengan bungkil wijen lokal sampai taraf $40 \%$ terjadi efek suplementer antara asam amino yang defisien sehingga memberikan efisiensi protein yang setara untuk dapat dikonversi menjadi daging. Dengan demikian ransum dengan substitusi $40 \%$ bungkil kedelai dengan bungkil wijen lokal masih dapat mencukupi kebutuhan asam amino yang seimbang dengan ransum kontrol yang tidak menggunakan bungkil wijen.

\section{KESIMPULAN}

Berdasar hasil penelitian dan pembahasan dapat disimpulkan bahwa sebanyak $40 \%$ dari jumlah bungkil kedelai yang dipergunakan menyusun ransum dapat diganti dengan bungkil wijen lokal tanpa mempengaruhi performan pertumbuhan maupun efisiensi penggunaan protein pada ayam broiler.
Bungkil wijen lokal dapat digunakan sebagai salah satu sumber protein sebanyak $10-13 \%$ dalam formula ransum.

\section{DAFTAR PUSTAKA}

Anggorodi,R. 1985. Kemajuan Mutakhir dalam Ilmu Makanan Ternak Unggas. Universitas Indonesia Press, Jakarta.

Aletor, I.I. Hamid dan E. Pfeffer. 2000. Low, protein, amino acidsupplemented diets in broiler chickens: Efect of performance, carcass characteristics, whole body composition and efficiencies of nutrient utilization. J. Sci Agric. 80: 547-554

Daghir, N.J., 1995. Feedstuffs Used in Hot Region. In Poultry in Hot Climats. N.J. Daghir. Ed. CAB International. Wallington. Oxon, UK.

Handayani, S., I. Astuti, Diffah H., E.Triharyanto dan Kusnandar. 2001. Studi Potensi Pengembangan Industri Berbahan baku Wijen di Kabuoaten Sukoharjo. Laporan Penelitian. Lembaga Pengabdian Pada Masyarakat Univ. Sebelas Maret. Surakarta.

Hartadi, H., S. Reksohadiprodjo dan A.D. Tillman. 1990. Tabel Komposisi Pakan untuk Indonesia. UGM Press, Yogyakarta.

Hutagalung, R. 1998. Nutritional value of Tropical Feed Resources for Chickens. Asian Pasific Poultry Congress. Nagoya, Japan.

Murtidjo, B. A. 2001. Pedoman Meramu Pakan Unggas. Cetakan 12. Penerbit Kanisius. Yogyakarta.

National Research Council. 1994. Nutrient Requirement of Poultry. $9^{\text {th }}$ Revised ed. National Academy of Science. Washington D.C, USA. 
Rasyaf, M. 1994a. Makanan Ayam Broiler. , M. 1994b. Beternak ayam, pedaging. Penerbit Swadaya. Jakarta.

Rizal, Y. 2000. Respon ayam broiler terhadap panggantian sebagian bungkil kedelai dengan bungkil inti sawit dalam ransum. Jurnal Peternakan dan Lingkungan. 6(2): 15-20.

Sibbald, I.R. 1980. The effect of level feed intke on metabolized energy value with adult roasters. Poultry Sci. 54:130-145
Kanisius. Yogyakarta.

Steel, R.G.D. dan Torrie, J.H. 1989.Principle and Procedures of Statistic a Biometrical Approach, $2^{\text {nd }}$ Ed. Mc Graw Hill Kogakusha, LTD.

Wahyu, J. 1997. Ilmu Nutrisi Unggas. Gadjah Mada University Press. Yogyakarta.

Wiradisastra, M.D.H. 1986. Efektivitas keseimbangan energi dan asam amino dan efisiensi absorpsi dalam menentukan persyaratan kecepatan tumbuh ayam broiler. Disertasi. Institut Pertanian Bogor, Bogor. 